\title{
Community Participation Concept in Supplement of Drinking Water Infrastructure and Sanitation for Sustainable Settlement Area Case Study Kelurahan Sukun, Sukun sub-district, Malang City
}

\author{
Hart Arsy Nesiaestetika \\ Department of Architecture Sepuluh Nopember Institute of \\ Technology Indonesia
}

\author{
Haryo Sulistyarso \\ Department of Urban and Regional Planning Sepuluh \\ Nopember Institute of Technology Indonesia
}

\author{
Eko Budi Santoso \\ Department of Urban and Regional Planning Sepuluh \\ Nopember Institute of Technology \\ Indonesia
}

\begin{abstract}
The development of the settlement in Malang is quite dynamic which is shown by the density of the building and the different conditions especially in urban slum areas. RW VI in Kelurahan Sukun is defined as urban slums located near riverbanks having some settlement problems such as the condition of the building, the limited availability of infrastructure, especially drinking water and sanitation also indiscriminate defecation and public indifference to environmental conditions. Various development programs have been implemented, but the community as a stakeholder has not been optimally participated and to achieve the target of $100 \%$ of drinking water and sanitation services as a form of sustainable settlements in RW VI that has been established to be the pilot settlement arrangement, still need the concept of settlement arrangement and community participation which are adjusted with local conditions of society.
\end{abstract}

The objective of this research is to create the concept of drinking water and sanitation infrastructure for sustainable settlements based on community. This research uses positivism approach with qualitative research method and supported by descriptive quantitative technique. To achieve that purposes, this research analyzes the characteristics of drinking water and sanitation management, the form of community participation, the factors that influence community participation and the level of community participation using by a quantitative-qualitative descriptive analysis which is combined with chi-square. The concept of community-based water supply and sanitation arrangement is done through delphy and qualitative descriptive analysis.

The result of this research is the characteristics of drinking water management and sanitation which has been involved in the community and legal with the cost of affordable services for lowincome people. The concept of drinking water and sanitation infrastructure arrangement encourages community participation in improving quality and services by arranging participation, rejuvenation, controlling and enhancing partnership management capability.

Keywords - Community Participation; Drinking Water Infrastructure and Sanitation

\section{INTRODUCTION}

Growth and urban agglomeration in Malang City become a big attraction for people to work, try and another purpose so that land in town become very valuable and its function tends to follow economic value. The role and function of Malang City as the centre of government, trade and services, education, and tourism make the limited land in the city has been used optimally even on lands that are not intended so that the city becomes more crowded and the arrangement of space becomes more complicated. One of the negative impacts of the city's development is the development of slum areas on unplanned low-cost lands that lack basic infrastructure, especially water and sanitation infrastructure.

Reflecting on the condition of slum areas in Malang City which is determined by Malang Mayor Decree in 2015 which spread in 29 villages with a total area of 608.60 ha or $5.2 \%$ of the city area. One of the priority locations of slum handling in Malang is RW VI in Kelurahan Sukun, Sukun Sub-district. From the hydrological side,this area is traversed by two rivers, the metro river and curse river so that the typology of settlements is a slum river settlement, the elevation is quite steep with dense houses. Some of the key issues concerning the slums of the RW VI are the acceleration of handling with the provision of sustainable drinking water and sanitation infrastructure and encouraging healthy behaviour change.

In encouraging the provision and management of drinking water and sanitation, the role of the community becomes very important. 100-0-100 Movement in order to achieve $100 \%$ target of drinking water service, $0 \%$ slums and $100 \%$ decent drinking water service could not be fulfilled only with government role only. Therefore, the participation of the community to optimize the provision and management of infrastructure, especially drinking water and sanitation becomes very important with the right concept and attention to local conditions. 
To create a no slum and sustainable city in Malang supported by the availability of quality and sustainability of drinking water supply and sanitation service especially in RW VI Kelurahan Sukun, the central government and the government of Malang City with various policies one of them is by arranging and improving the quality of slums. Structuring and improving the quality of slums has been done by accelerating the development and service of basic infrastructure especially the availability of drinking water and proper sanitation.

With the implementation of clean water and sanitation infrastructure arrangement program, there have been changes both in terms of the quality of settlements and the environment and community behaviour. Nevertheless, to achieve the $0 \%$ slum handling target andthe $100 \%$ availability of drinking water and sanitation through the provision of infrastructure with networks and communal systems still, require considerable effort because the current drinking water service in RW VI is still $78.4 \%$ and sanitation $65.8 \%$.

From this condition, community involvement in the planning, implementation and management/maintenance of drinking water and sanitation infrastructure in RW VI requires an innovative conceptualization concept regard to the current condition, the participation orientation, the factors that influence participation and the level of community participation. Because the trend has positioned the community into a host with community participation and the right concept will be able to make the community tend to have a sense of responsibility towards the infrastructure and environment so that the burden of government in providing basic housing settlement services will eventually be increasingly lighter due to the increasingly independent community.

The objective of this research is to formulate the concept of the arrangement of drinking water infrastructure and sustainable sanitation based on community participation. While the targetresearch is: 1) Identify the characteristics of water and sanitation infrastructure management; 2) Analyze the form and factors that influence community participation in the arrangement of drinking water and sanitation infrastructure; 3) Analyze the level of community participation in the arrangement of drinking water and sanitation infrastructure; 4) Formulate the concept of development of community-based drinking water and sanitation infrastructure. Further benefits to be achieved in this research are 1) Theoretical benefits, this research can be used as input to the concept of community-based sustainable settlement arrangement; 2) Practical Benefits, for the local government of Malang City, East Java Provincial Government and Central Government can be used as evaluation material to prepare policies and program of arrangement of drinking water and sanitation infrastructure for settlement with community participation in the next year

\section{METHODOOGY}

\section{A. Approach and Type of Research}

The research approach used in this research is positivism approach and this research type is descriptive qualitative research supported by quantitative method.

\section{B. Research Variables \\ Variables used in this research are:}

1. Characteristics of drinking water and sanitation management: service system; streaming system; service costs and management organizations.

2. A form of community participation: Physical participation includes building materials; money; food/beverages, while non-physical participation includes: attendance at meetings; the ideas propagation andpersonal participation.

3. Factors that affect community participation: Internal factors include gender; age; work; income and education while external factors include the role of government; the role of community leaders; culture and perceptions of infrastructure needs.

4. The level of community participation using 8 Arnsteinsteps, they are Therapy, Notice, Consultation, Peace,Partnership, Delegation, Power, and Community Control analyzed through attendance, active to give opinions, participation in physical/development activities and role in management/post development.

\section{Sample and ResearchRespondent}

To obtain optimal questionnaire information related to factors influencing community participation, the study population is adult population (17 years and above) whose number in RW VI is 1,670 people. After inserted with solving formula then obtained result 94.35 people and can be rounded to 95 responders. This step also conducted by the interview process. Determination of interview respondents was done by Purposive Sampling method to 15 people who are considered to have information and knowledge.

D. Identify the condition characteristicsand management of drinking water and sanitation infrastructure.

To know the characteristics of the condition and drinking water management and sanitation infrastructure, a qualitative analysis was conducted. There are 3 stages to obtain valid data, there are data reduction (observation, primary and secondary), data presentation and conclusion.

\section{E. Identify the Forms of Community Participation}

To know the characteristics of condition and management of drinking water and sanitation infrastructure, a qualitative analysis was conducted. There are 3 stages to get valid data, that is data reduction (the result of questioner and interview), data presentation and drawing conclusion

\section{F. Factors that influence community participation}

To see whether there is a relationship between external and internal factors with community participation in the planning process; implementation and management, the researcher used statistical analysis of chi-square test. Chisquare test is used to find whether there is an association between variables whereas contingency coefficient is used to see how strong the relationship of two variables tested. Hypothesis testing will be done by using the significance level $(\alpha=0,05)$. 
G. Participation level in the arrangement of drinking water infrastructure and sustainable sanitation

The researcher used the descriptivequantitative method to analyze the level of community participation. The results of the questionnaires were classified with the level of community participation obtained through scoring the results of the questionnaires conducted in the study area. From 1 (one) question there are 5 (five) answer choices with scores ranging from 1 to 5 with 4 questions. Thus from each individual will get a minimum score of 1 , that is $1 \mathrm{x} 1$ and the maximum score for each individual is 5 , that is from $1 \times 5$. If the number of respondents is 95 people, the minimum score for community participation level is $95 \times 1 \times 4=380$ and the maximum score of the community participation level is $95 \times 5 \times 4=1.900$. After the minimum and maximum scores are found the interval range is (1.900-380) $/ 8=190$. So by using the typology of Arnstein with 8 levels of participation then scoring the level of public participation are:

$\begin{aligned} 1900 & \\ 1710 & \text { Citizen Control } \\ 1520 & \text { Delegated Power } \\ 1330 & \text { Partnership } \\ 1140 & \text { Placation } \\ 950 & \text { Consultation } \\ 760 & \text { Informing } \\ 570 & \text { Therapy } \\ 380 & \text { Manipulation }\end{aligned}$

H. The concept of drinking water infrastructure development and sanitation sustainable based on community

In identifying the problem factors in the development of drinking water and sanitation, the researcher used Delphi analysis tools. Stages of Delphi analysis conducted in the study include:

1) Specification Problems

Determine the issues that will be discussed and commented upon by the respondents

2) Formulate Questionnaire.

Determine the points to be included in the questionnaire in the form of questionnaires to be used in the first and subsequent rounds.

3) Delphi Interview Round I

Stakeholder interviews for the exploration of influencing factors after knowing the key stakeholders gained from stakeholder analysis.

4) Analysis of Interview Results

Analysis of interview results is data reduction which is the process of selecting, focusing, simplifying, summarizing and transforming data from the transcript of the interview result.

5) Iteration and Withdrawal Conclusion

Iteration is done to ensure (cross-check) whether the factors that influence based on the results of summary interviews in accordance with the intent provided by each stakeholder.

After obtaining the key problems then the researcher drafted the concept of drinking water infrastructure development and sanitation sustainable based on community with descriptive qualitative based on the results of interviews, literature and policy.

\section{DISCUSSION}

A. Identification the Characteristics of Conditions and Drinking Water Infrastructure Management

After collecting data and information from primary data, secondary and field observation, data validation and data reduction can be explained that the characteristics of drinking water and sanitation management in RW VI are: Drinking water and sanitation system is a network system of pipes and SR. Drinking water services are served by a pipeline network equipped with reservoir towers which are flowed with gravity system, while for sanitation also have communal networks using 2 wastewater treatment plant; The drainage system of both water pipe and sanitation systems rely on the gravity system because it has been supported by fairly steep topographic conditions; the cost of drinking water and sanitation services in RW VI can be reached by low-income people even cheaper than the services provided by Water Supply Company and private drinking water at a price of 1,000 - 1.250 IDR per $\mathrm{m}^{3}$ and waste service is 1,000 IDR per month and the organization of both drinking water and sanitation management has been legalized by HIPPAM and KKP Sanitation.

\section{B. Forms of Community Participation.}

Laksana (2013), argues that the form of community participation can be used for innovative program development. Forms of participation provided by citizens could be in the form of manpower in the work of physical devotion, property and also the presence and thoughts at the citizenmeetings. From the analysis conducted in the implementation of drinking water supply and sanitation in RW VI, based on surveys and observations at the study sites and the results of questionnaires, it produces prominent forms of community participation in every stage of implementation. At the planning stage, the form of participation in the form of food, attendance and ideas are very dominant given the community through forums of community meetings. In the implementation stage, the forms of participation in the form of food, money, materials, attendance, ideas and energy are given by the community during physical development through community service work, while in the operational phase of the maintenance of participation in the form of money, attendance, ideas and energy usually given by the community in RW VI.

\section{Factors Affecting Community Participation}

Community participation can basically be influenced by several things such as the level of education, the expected needs/conditions and the presence of community leaders (Andreeyan, 2014). By knowing the factors that encourage community participation, participation innovation will encourage better participation and awareness level of participation in the future. After distributing questionnaires to the respondents in RW VI, which amounted to 96 respondents, the researcher performs the data analysis by using SPSS ver.16 application. The data and analysis are done by tools of crosstabulation and chi-square. This analysis was done to measure whether there is a significant relationship between internal factors with the process of community participation either at the planning stage, development implementation or in the postimplementation/operational/maintenance phase. 
Table 1.The result of Probability Significance Value Analysis from Chi-Square

\begin{tabular}{|c|c|c|c|c|c|}
\hline \multirow[b]{2}{*}{$\begin{array}{l}\mathbf{N} \\
\mathbf{0}\end{array}$} & & & \multicolumn{3}{|c|}{ Nilai Chi-Square } \\
\hline & & & $\begin{array}{c}\text { Planning } \\
\text { Process }\end{array}$ & $\begin{array}{c}\text { Implement } \\
\text { ation } \\
\text { Process }\end{array}$ & $\begin{array}{c}\text { Post/Operat } \\
\text { ional } \\
\text { Process }\end{array}$ \\
\hline 1. & \multirow{5}{*}{$\begin{array}{c}\text { Interna } \\
1 \\
\text { Factor }\end{array}$} & Age & 0,010 & 0,105 & 0,020 \\
\hline 2. & & Gender & 0,330 & 0,740 & 1,000 \\
\hline 3. & & Education & 0,001 & 0,012 & 0,007 \\
\hline 4. & & Employment & 0,025 & 0,004 & 0,065 \\
\hline 5. & & Income & 0,181 & 0,218 & 0.001 \\
\hline 1. & \multirow{4}{*}{$\begin{array}{l}\text { Extern } \\
\text { al } \\
\text { Factor }\end{array}$} & Governemnt & 0,000 & 0,515 & 0,000 \\
\hline 2. & & $\begin{array}{l}\text { Community } \\
\text { Figure }\end{array}$ & 0,785 & 0,000 & 0,829 \\
\hline 3. & & $\begin{array}{l}\text { Infrastrucutu } \\
\text { re Needs }\end{array}$ & 0,001 & 0,136 & 0,001 \\
\hline 4. & & Culture & 0,168 & 0,020 & 0,685 \\
\hline
\end{tabular}

Green color (value significansi $<0,05$ ) = have influence

Source: Analysis Result, 2018

The probability value (Asymp.Sig) $<0.05$ then $\mathrm{HO}$ is rejected means the state that the two variables tested are interconnected must be accepted (Siagian, 2006). From Table 1, it can be obtained that:

1. In the planning process, the factors that influence community participation are age, education, employment, government and infrastructure needs.

2. In the implementation process, the factors that influence community participation are education, employment, community figures and culture.

3. In post-activity/management/maintenance, factors affecting community participation are age, education, income,government, and infrastructure needs.

\section{Level of Participation in Structuring of Sustainable Drinking Water and Sanitation}

To analyze the level of community participation in the provision of drinking water and sanitation infrastructure in RW VI KelurahanSukun, Sukun Sub-district, Malang City using Arnstein's theory. The degree or level of community involvement is measured by the attendance variables in the meetings, the liveliness in the discussions, the involvement in physical activity and the agreement to pay contributions/involvement in the institution.

Table 2. Recapitulation of Community Participation Score

\begin{tabular}{|c|c|c|}
\hline Stages of The Program & Activities & Score \\
\hline Planning & $\begin{array}{l}\text { 1. Attendance level in the } \\
\text { meetings } \\
\text { 2. Level of activity in discussing } \\
\text { and expressing opinions }\end{array}$ & $\begin{array}{l}329 \\
301\end{array}$ \\
\hline Implementation & $\begin{array}{l}\text { 1. Level of activity in the } \\
\text { physical activity }\end{array}$ & 280 \\
\hline Operational & $\begin{array}{l}\text { 1. Participate in organizations } \\
\text { and financing for sustainability }\end{array}$ & 293 \\
\hline & Score Total & 1.203 \\
\hline
\end{tabular}

$\begin{array}{lll}1900 & & \\ 1710 & \begin{array}{l}\text { Citizen Control } \\ \text { Delegated }\end{array} & \begin{array}{l}\text { From the survey results involving } \\ \text { respondents, it can be seen that the participation } \\ \text { level of RW 6 Kelurahan Sukun community in } \\ \text { the planning implementation and post- } \\ \text { implementation/operational process in the } \\ \text { provision of drinking water and sanitation } \\ \text { infrastructure on Placation criteria with a total } \\ \text { score of } 1,203 .\end{array}\end{array}$
950 Consultation
760 Informing
570 Therapy
380 Manipulation

E. The concept of Community Participation in Structuring Water and Sanitation Infrastructure

In preparing the concept of community participation in the arrangement of drinking water infrastructure and sanitation slum settlement area in RW VI Kelurahan Sukun, Sub-district Sukun, Malang city certainly needs to explore various issues and challenges that exist based on real conditions and respondent data. Furthermore, Delphi analysis was conducted on 15 influential respondents selected through stakeholder analysis. The analysis was done in two steps to find consensus and appropriate answers. This Delphi analysis passes through 2 stages of iteration so that 13 factors are found to be fundamental things that need to be considered in preparing the concept of participation is as follows:

1. System performance needs improvement especially related to NRW and pipeline network quality;

2. Topographic conditions resulted in not being able to meet/serve the needs of all citizens;

3. The capacity system and the idle must be taken into account to serve the needs of the community both the infrastructure of drinking water and sanitation;

4. The existence of budget constraints to change Community-Based Healthy Life Behavior to target communities;

5. Coordination between stakeholders, they are between government, community, management, village and private groups;

6. The community supports the participation of infrastructure financing to support the sustainability of community-managed drinking water and sanitation services;

7. The community has participated in the form of attendance, providing input and engaging in decision making;

8. Need to transfer knowledge about various aspects of the Government/companion to the community, especially the management group;

9. Sustainability of community management of drinking water and sanitation infrastructure can be threatened if network damage, lack of fund allocation for managerial performance, and no maintenance of local water resources;

10. The government needs to provide facilitation and institutional facilitation as well as budget support for system maintenance;

11. Availability of operational and maintenance funds;

12. Development of both capacity and network systems still need external support (government / CSR).

13. The community must be self-reliant in solving problems arising during community meetings, implementation of activities, and maintenance. The function of the government can only be a facilitator. 
Table 3. The concept of Participation to Support Sustainability

\begin{tabular}{|c|c|c|}
\hline $\begin{array}{l}\text { SUSTAINABLE } \\
\text { CONCEPT }\end{array}$ & $\begin{array}{l}\text { POTENTIALS AND } \\
\text { CHALLENGES } \\
\text { BASED ON DELPHI } \\
\text { ANALYSIS }\end{array}$ & $\begin{array}{l}\text { PARTICIPATION } \\
\text { CONCEPT }\end{array}$ \\
\hline $\begin{array}{l}\text { 1. The result of } \\
\text { Infrastructure } \\
\text { development } \\
\text { works and can be } \\
\text { used }\end{array}$ & $\begin{array}{l}\text { The government } \\
\text { needs to provide } \\
\text { facilitation and } \\
\text { institutional } \\
\text { facilitation as well } \\
\text { as budget support } \\
\text { for system } \\
\text { maintenance. } \\
>\text { Development of } \\
\text { both capacity and } \\
\text { network system still } \\
\text { needs external } \\
\text { support } \\
\text { (government / } \\
\text { CSR). }\end{array}$ & $\begin{array}{l}\text { - After being built } \\
\text { more than } 5 \text { years } \\
\text { ago, the drinking } \\
\text { water service system } \\
\text { in RW VI is still } \\
\text { functioning well. } \\
\text { Although not yet } \\
\text { able to serve } 100 \% \text {. } \\
\text { In the future, } 2 \\
\text { strategies of } \\
\text { participation are } \\
\text { used. } \\
\text { 1. For low- } \\
\text { income society } \\
\text { to be included } \\
\text { in the } \\
\text { agriculture } \\
\text { drinking water } \\
\text { grant program, } \\
\text { it can be done } \\
\text { for free or } \\
\text { conducted by } \\
\text { SR arisan; } \\
\text { 2. For the public } \\
\text { are able to be } \\
\text { charged with } \\
\text { the concerned } \\
\text { with the cost } \\
\text { agreed upon } \\
\text { by the citizens } \\
\text { and set forth in } \\
\text { the standard } \\
\text { operating } \\
\text { procedures. } \\
\text { HIPPAM managers } \\
\text { are encouraged to } \\
\text { improve both } \\
\text { technical and } \\
\text { administrative } \\
\text { capacity. }\end{array}$ \\
\hline $\begin{array}{l}\text { 2. Providing services } \\
\text { as planned, } \\
\text { including meeting } \\
\text { the quality and } \\
\text { quantity of water } \\
\text { required, } \\
\text { accessible } \\
\text { services, reliable } \\
\text { and continuous } \\
\text { services, having } \\
\text { economic and } \\
\text { health benefits }\end{array}$ & $\begin{array}{l}\text { Topographic } \\
\text { conditions and } \\
\text { organizational } \\
\text { capacity result in } \\
\text { not being able to } \\
\text { serve the needs of } \\
\text { all citizens. }\end{array}$ & $\begin{array}{l}\text { - HIPPAM } \\
\text { Institutionmust be } \\
\text { upgraded and } \\
\text { division/section } \\
\text { divided according to } \\
\text { a response from the } \\
\text { start of the financial } \\
\text { administration, } \\
\text { maintenance, } \\
\text { development/invest } \\
\text { ment }\end{array}$ \\
\hline $\begin{array}{l}\text { 3. Can function over } \\
\text { a long period of } \\
\text { time depending } \\
\text { on the life cycle } \\
\text { of the tool that } \\
\text { has been designed } \\
\text { and the } \\
\text { independence of } \\
\text { management }\end{array}$ & $\begin{array}{l}\text { Community } \\
\text { management } \\
\text { sustainability of } \\
\text { drinking water and } \\
\text { sanitation } \\
\text { infrastructure can } \\
\text { be threatened if } \\
\text { tissue damage, lack } \\
\text { of fund allocation } \\
\text { for managerial } \\
\text { performance, and } \\
\text { no maintenance of } \\
\text { local water } \\
\text { resources. } \\
\text { The capacity of the } \\
\text { system and the idle } \\
\text { must be taken into } \\
\text { account to serve the }\end{array}$ & $\begin{array}{l}\text { After operating for } \\
\text { more than } 5 \text { years, } \\
\text { the maintenance unit } \\
\text { should frequently } \\
\text { check the } \\
\text { pipeline/network } \\
\text { especially on the } \\
\text { connections and the } \\
\text { control basin. }\end{array}$ \\
\hline
\end{tabular}

\begin{tabular}{|c|c|c|c|}
\hline & & $\begin{array}{l}\text { needs of both the } \\
\text { water and sanitation } \\
\text { infrastructure. }\end{array}$ & \\
\hline $\begin{array}{l}\text { 4. Service } \\
\text { management } \\
\text { involves } \\
\text { community/comm } \\
\text { unity }\end{array}$ & $>$ & $\begin{array}{l}\text { Coordination } \\
\text { between } \\
\text { stakeholders, ie } \\
\text { between } \\
\text { government- } \\
\text { community- } \\
\text { management- } \\
\text { village-private } \\
\text { groups } \\
\text { The community } \\
\text { supports the } \\
\text { participation of } \\
\text { infrastructure } \\
\text { financing to support } \\
\text { the sustainability of } \\
\text { community- }\end{array}$ & $\begin{array}{l}\text { The management of } \\
\text { HIPPAM currently } \\
\text { involves the } \\
\text { community. It } \\
\text { should be } \\
\text { encouraged, } \\
\text { however, that in AR } \\
\text { ART there are } \\
\text { points related to the } \\
\text { change/consultation } \\
\text { mechanism of the } \\
\text { evaluation of the } \\
\text { management so that } \\
\text { people with the } \\
\text { potential and ability } \\
\text { to participate }\end{array}$ \\
\hline
\end{tabular}

managed drinking

water and sanitation services

$>$ The community has participated in the form of attendance, providing input and engaging in

decision making

$>$ The community must be self-reliant in solving the problems that arise during community meetings, implementation of activities, and maintenance. The function of the government can only be a facilitator.

\begin{tabular}{|c|c|}
\hline $\begin{array}{l}\text { 5. The costs of } \\
\text { operating, }\end{array}$ & $\begin{array}{l}\text { The existence of } \\
\text { budget constraints }\end{array}$ \\
\hline
\end{tabular}
repairing, replacing, and to change Community-Based Healthy Life administering Behavior to target services are affordable at the local level communities

Availability of operational and maintenance funds

residents who use drinking water services has been able to cover the operating costs of the monthly system. But for the operational cost of managers and development and maintenance is still not meet so that still remain dependent on external parties. But the community can participate by proposing it in the deliberation of development plans to be funded by the other party.

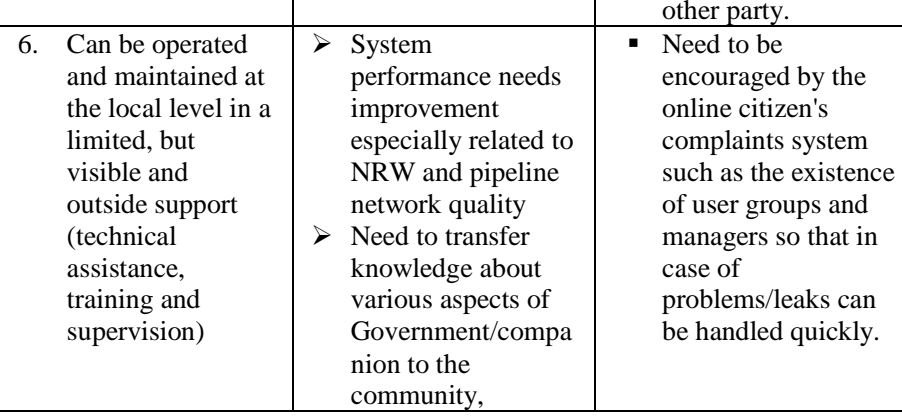




\section{CONCLUSION}

From the results of the above discussion, it can be concluded from this research:

1. Factors that affect the community among others are internal factors that affect age, education, employment, external factors of government and infrastructure needs.

2. Participation level of RW VIin community planning, implementation and post-implementation/operational processes in the provision of drinking water and sanitation infrastructure on Placation criteria. This means that the community has been able to communicate with the government well and there is negotiation/cooperation between community/community representatives and the government. The community provides more significant inputs in determining decision outcomes, but the decisionmaking process is still in the hands of the government and dependence on large governments especially on the planning and operational processes in accordance with the outcomes of external factors affecting the operationalimplementation process.

3. The concept that can be applied for community participation in the arrangement of drinking water and sanitation infrastructure for sustainable settlement is the concept of drinking water management through community empowerment. Service in accordance with the planning, including meeting the quality and quantity of water required, the service is easily accessible, reliable and continuous and has benefits in the field of economy and health and can function in the long term, can be operated and maintained at the local level.

\section{REFERENCES}

[1] Andreeyan, Rizal (2014), Studi tentang Partisipasi Masyarakat dalam Pelaksanaan Pembangunan di Kelurahan Sambutan, Kecamatan Sambutan, Kota Samarinda. eJournal Administrasi Negara, 2014. ejournal.an.fisip-unmul.org

[2] Laksana, Nuring Septyasa (2013), Bentuk-Bentuk Partisipasi Masyarakat dalam Program Desa Siaga di Desa Bandung, Kecamatan Playen, Kabupaten Gunung Kidul, DIY. Journal Kebijakan dan Administrasi Publik Volume 1, Nomor 1 Year 2013

[3] Siagian, Dergibson dan Sugiarto. (2006). Statistika Untuk Bisnis dan Ekonomi. PT Gramedia Pustaka Utama. Jakarta. 